\title{
Inhalt, Vol. 1, No. 3, 1978
}

\section{Contents}

Impressum Ill

Tulzer, H. und Kupka, St., Wien

Das Ausmaß des Karzinombefalles der regionalen

Lymphknoten beim Zervixkarzinom und sein Einfluß auf

die Heilungsresultate. (Ein Bericht über 103 geheilte

Fälle) 89

Wannenmacher, M. und

Knüfermann, H., Freiburg i.Br.

Fortschritte in der Therapie des Medulloblastoms

Kokoschka, E.-M.; Luger, Th. und

Micksche, M., Wien

Immuno-Chemotherapie bei Patienten mit disseminiert metastasierendem Melanom Stadium III. Randomisierte Studie mit Methyl-CCNU versus C.parvum plus MethylCCNU 98

Buchbesprechung 105

Micksche, M.; Kokoschka, E.-M.; Sagaster, P. und Kofler, K., Wien

Klinische und immunologische Untersuchungen mit

OK-432 (Streptococcus pyogenes) zur Immuntherapie

bei Krebspatienten 106

Rella, W.; Winterleitner, H.; Pawlowski, J.;

Kummer, M. und Krepler, P., Wien

Die prognostische Bedeutung der Lymphozytentransformierbarkeit durch Phythämagglutinin bei Kindern mit akuter lymphatischer Leukämie 113

BAUER, H. W.; Bohn, H. und Ax, W., Marburg/Lahn

Immunologische Potenz des schwangerschaftsassoziier-

ten Alpha2-Glykoproteins (Alpha2-PAG) . . • 119

Friedl, H. P. und Wrba, H., Wien

Lungenkrebsrisiko und »Raucherprophylaxe« in öster-

reich 124

Lapin, V., Wien

Die phylogenetischen Aspekte der erworbenenlmmunität 128

Imprint Ill

Tulzer, H. and Kupka, St., Vienna

The Extent of Carcinomatous Involvement of the Re gional Lymph Nodes in Cervical Carcinoma and its In 
fluence on the Therapeutic Results. (A Report on 103

Cured Cases) 89

Wannenmacher, M. and

Knüfermann, H., Freiburg i. Br.

Advances in Medulloblastoma Therapy

92

Kokoschka, E.-M.; Luger, Th., and

Micksche, M., Vienna

Immuno-chemotherapy of Disseminated Malignant

Melanoma Stage III. Randomized Trial Comparing

Methyl-CCNU versus Corynebacterium parvum plus

Methyl-CCNU

98

Book Review 105

Micksche, M.; Kokoschka, E.-M.; Sagaster, P., and Kofler, K., Vienna

Clinical and Immunological Investigations with OK-432

(Streptococcus pyogenes) for Immunotherapy in Cancer

Patients 106

Rella, W.; Winterleitner, H.; Pawlowski, J.;

Kummer, M., and Krepler, P., Vienna

The Response of Lymphocytes to Phytohemagglutinin in

Children with Acute Lymphatic Leukemia 113

Bauer, H. W.; Bohn, H., and Ax, W., Marburg/Lahn

Immunological Valence of the Pregnancy-associated

Alphaa-Glycoprotein (Alpha2-PAG) 119

Friedl, H. P. and Wrba, H., Vienna

Lung Cancer Risk and Smoking Control in Austria . . . .124

Lapin, V., Vienna

The Phylogenetic Aspects of Acquired Immunity 